\title{
Genome Stability Requires p53
}

\author{
Christine M. Eischen \\ Department of Pathology, Microbiology, and Immunology, Vanderbilt University Medical Center, Nashville, \\ Tennessee 37212 \\ Correspondence: christine.eischen@vanderbilt.edu
}

It is now clear that functional p53 is critical to protect the genome from alterations that lead to tumorigenesis. However, with the myriad of cellular stresses and pathways linked to p53 activation, much remains unknown about how p53 maintains genome stability and the proteins involved. The current understanding of the multiple ways p53 contributes to genome stability and how two of its negative regulators, Mdm2 and Mdmx, induce genome instability will be described.

$\mathrm{R}_{\mathrm{a}}^{\mathrm{ec}}$ ecently, genome instability was recognized as hallmark of cancer (Hanahan and Weinberg 2011). Genome instability can be structural and/or numerical abnormalities in chromosomes and includes such alterations as chromosome or chromatid breaks, insertions, deletions, translocations, fusions, gain or loss of one or more chromosomes (aneuploidy), gain of part or an entire genome (polyploidy and tetraploidy), and centrosome amplification (Lengauer et al. 1998; Negrini et al. 2010). Cells that acquire or accumulate these abnormalities are considered to have unstable genomes. Most cancers have genome instability that often manifests as aneuploidy or polyploidy. However, with coding regions or entire genomes from thousands of cancers now sequenced, it is apparent that malignancies typically have multiple genomic abnormalities that can be small and/or large. There is a range of alterations between different cancers with those that have links to DNA-damaging agents (e.g., melanoma and lung cancer) having more genomic instability (Lawrence et al. 2013).
With most malignancies showing some form of genome instability and also lacking a functional p53 pathway, a link between p53 inactivation and genome instability was hypothesized. What has become clear over the last two decades of research is that many genes involved in cell-cycle control and the DNA-damage response have important roles in genome stability (Aguilera and Garcia-Muse 2013; Beishline and Azizkhan-Clifford 2014). These genes are the first line of defense for cells to maintain a stable genome by preventing genomic alterations from being passed onto progeny. The tumor suppressor p53 is one of these genes. A multitude of cellular stress signals funnel to p53, only some of which induce or are a result of DNA damage that can negatively impact genome stability. Data have revealed just how critical p53 is for maintaining the stability of the genome in the face of genomic insults that cause DNA damage. Because cancers appear to thrive on some level of genome instability, there is significant selective pressure to inactivate $\mathrm{p} 53$, which occurs

Editors: Guillermina Lozano and Arnold J. Levine

Additional Perspectives on The p53 Protein available at www.perspectivesinmedicine.org

Copyright (C) 2016 Cold Spring Harbor Laboratory Press; all rights reserved; doi: 10.1101/cshperspect.a026096

Cite this article as Cold Spring Harb Perspect Med 2015;6:a026096 


\section{C.M. Eischen}

in more than $50 \%$ of human malignancies (Eischen and Lozano 2014). Moreover, two proteins that regulate $\mathrm{p} 53, \mathrm{Mdm} 2$ and $\mathrm{Mdmx}$, also have been shown to significantly influence genome stability, and these are used by cancer cells to increase genome instability through both p53-dependent and p53-independent mechanisms (Melo and Eischen 2012).

\section{p53-INDUCED PATHWAYS THAT PREVENT GENOME INSTABILITY}

Primarily through its transcription factor function, p53 has the ability to induce cell-cycle arrest and apoptosis (Fig. 1), both of which protect the cell and the organism from DNA damage that leads to genome instability (Eischen and Lozano 2014). Cell-cycle arrest caused by transcriptional up-regulation of the cell-cycle inhibitor p21 (Cdkn1a) by p53 is a well-char- acterized response to multiple forms of DNA damage and cellular stress (el-Deiry et al. 1993; Harper et al. 1993). p53 transcriptionally up-regulates other genes (e.g., Gadd45a) that also inhibit cell-cycle progression. Although less understood, p53 has been reported to inhibit the translation of cell-cycle genes, such as $C d k 4$, which would result in $\mathrm{G}_{1}$ cell-cycle arrest (Ewen et al. 1995). Senescence, which is considered a permanent exit from the cell cycle, is also mediated by p53 (Serrano et al. 1997). Senescence remains an incompletely understood effect of p53 activation, but occurs in cells in which there is telomere shortening, overexpression, or hyperactivation of an oncogene, or oxidative damage (Campisi 2005). p21 has been shown to be involved in p53-mediated senescence (Fig. 1), but it is not sufficient on its own (Brown et al. 1997; Pantoja and Serrano 1999). Other p53 target genes (e.g., PML and

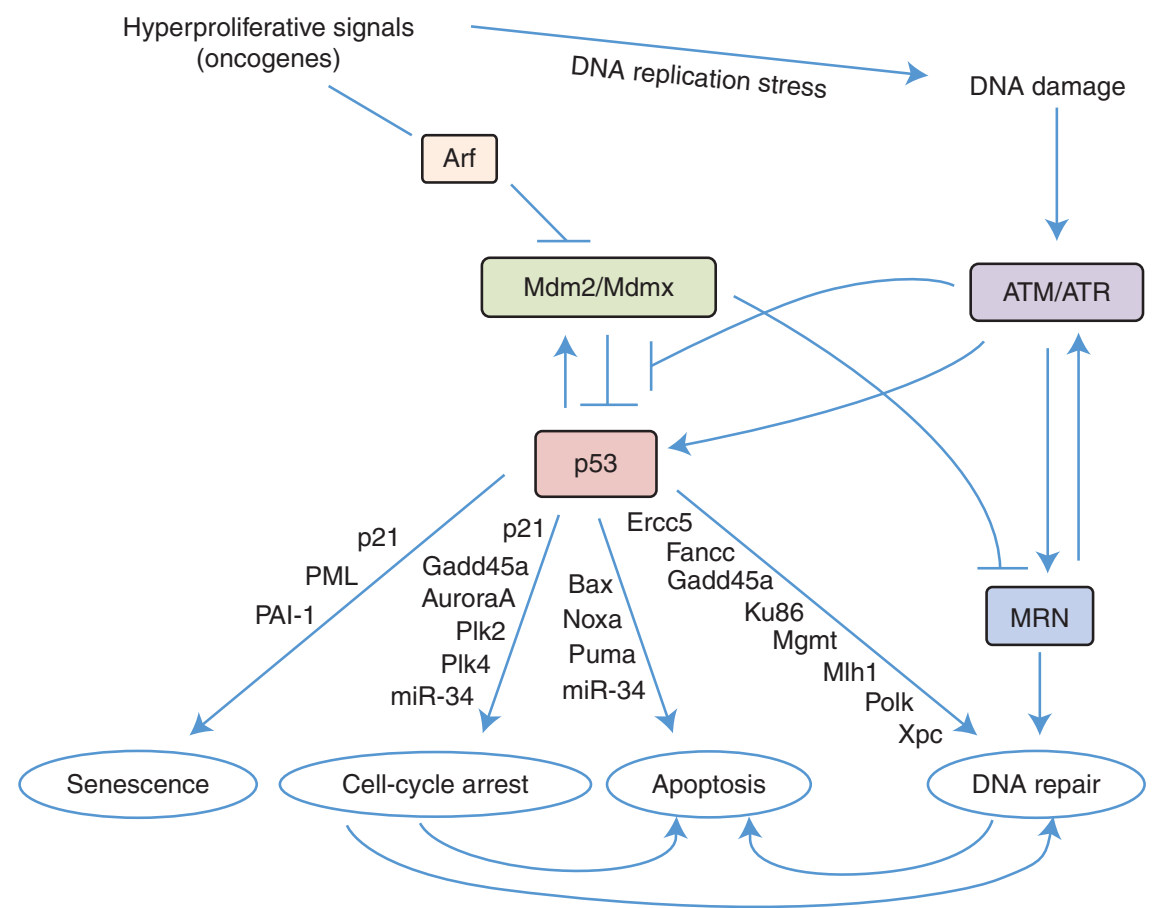

Figure 1. p53 activation and the upstream regulators and downstream effectors. p53 is activated by hyperproliferation through Arf activation and DNA-damage signaling through modulation of Mdm2 and activation of the DNA-damaged ataxia-telangiectasia mutated (ATM) and/or ATM- and RAD3-related (ATR) kinase. Activation of $\mathrm{p} 53$ induces the transcriptional up-regulation of one or more target genes that mediate one of the biological effects indicated. A cell-cycle arrest caused by checkpoint activation and DNA damage that is not repairable can ultimately induce apoptosis. MRN, Mre11/Rad50/Nbs1. 
$P A I-1)$ have also been linked to senescence (de Stanchina et al. 2004; Kortlever et al. 2006).

In addition to cell-cycle arrest, p53 can also signal for apoptosis to kill cells that have damaged DNA. Although p53-mediated apoptosis has been extensively studied, there are still many aspects that remain unclear. Following various kinds of DNA damage, p53 transcriptionally activates the proapoptotic genes $B a x$, Noxa, and/or Puma (Fig. 1), which inhibit the antiapoptotic $\mathrm{Bcl}-2$ proteins resulting in apoptosis induction (Miyashita and Reed 1995; Oda et al. 2000; Nakano and Vousden 2001; Yu et al. 2001; Czabotar et al. 2014). Additionally, p53 is also postulated to function at mitochondria where it physically inhibits antiapoptotic Bcl-2 family members resulting in apoptosis (Mihara et al. 2003; Chipuk et al. 2004; Galluzzi et al. 2011). What dictates which proapoptotic gene(s) to transcribe or whether to locate to mitochondria is unknown. Complicating the situation further, p53 has also been linked to other forms of cell death, such as necrosis and autophagy (Crighton et al. 2006; Vaseva et al. 2012), which also may contribute to maintaining the genome.

p53 is classified as a gatekeeper or a hub protein in that it appears to determine whether a cell-cycle block is needed to allow cellular repair to take place or whether damage is too great or persisting too long and apoptosis should occur instead. How p53 decides which avenue (cellcycle arrest, senescence, or apoptosis) to take is under intense research, and likely involves the strength and duration of the signal, the amount and kind of cellular damage, the transcriptional cofactors and epigenetic modulators recruited, the affinity of p53 for the promoter, and the cell type (Carvajal and Manfredi 2013). Regardless of whether apoptosis, cell-cycle arrest, or senescence is induced by p53, the outcome is that a cell with damage should not be allowed to proliferate, protecting the genome.

\section{DNA DAMAGE ACTIVATES p53}

Many cellular stress signals activate p53, but not all of these contribute to genome instability. DNA damage is a cellular stress that is the pri- mary cause of genome instability. DNA damage can manifest from single- or double-strand DNA breaks, DNA cross-links, replication stress/replication fork collapse, telomere attrition, and nucleotide depletion, among others. p53 is a critical mediator of DNA-damage signaling that facilitates DNA repair. Following DNA damage, DNA repair proteins are rapidly activated (Fig. 1). Specifically, DNA-damaged kinases, such as ataxia-telangiectasia mutated (ATM) and/or ATM- and RAD3-related (ATR), are activated and phosphorylate many proteins, including the kinases Chk1 and/or Chk2 and Nbs1 of the Mre11/Rad50/Nbs1 (MRN) DNA repair complex, Mdm2, and p53, to signal that DNA damage has occurred (Shiloh and Ziv 2013). The phosphorylation of Mdm2 by ATM is thought to disrupt Mdm2:p53 interaction and results in stabilization of p53 and p53 transcriptional activation (Shieh et al. 1997; Gannon et al. 2012). p53 transcriptionally up-regulates numerous genes that are involved in various DNA repair mechanisms (e.g., Ercc5, Fancc, Gadd45a, Ku86, Mgmt, Mlh1, Msh2, Polk, Xpc, and others). Cells that lack functional ATM have reduced p53 activation and $\mathrm{G}_{1}$ cell-cycle arrest following DNA damage. Humans that have a loss-of-function mutation in ATM are sensitive to $\gamma$ radiation (Lavin and Shiloh 1997). Mutations in p53 can also reduce ATM activation and lead to genome instability. Specifically, expression of a mutant $\mathrm{p} 53, \mathrm{p} 53^{\mathrm{R} 248 \mathrm{~W}}$, in U2OS cells resulted in reduced localization of ATM to sites of DNA damage and phosphorylation of an ATM target, H2AX. Moreover, thymocytes in mice engineered to express $\mathrm{p} 53^{\mathrm{R} 248 \mathrm{~W}}$ have increased interchromosomal translocations between T-cell receptors, an indicator of genome instability in these cells (Song et al. 2007). Stimuli that induce DNA damage that does not kill the cell and that is not repaired can result in chromosome breaks and translocations. This can occur when cells are allowed to continue cycling in the presence of DNA damage. It remains poorly understood why some DNA damage cannot be repaired properly, and why a cell with wild-type p53 is not able to hold the cellcycle arrest for the correct repair to occur or induce apoptosis if it cannot. Recently, however, 


\section{C.M. Eischen}

reduced 553 acetylation was shown to inhibit its binding-to-target gene promoters following DNA damage, resulting in a lack of a $\mathrm{G}_{2} / \mathrm{M}$ cell-cycle arrest in some situations (Reed and Quelle 2014). Thus, proteins that regulate p53 transcriptional activity are likely to have significant roles in genome stability and should be investigated. Therefore, a functional DNA-damage response that includes p53 is essential to repair DNA and prevent acquiring DNA aberrations that lead to genome instability.

Oncogenes, which cause hyperproliferative signals, including DNA replication stress that can lead to DNA damage, activate p53 (Hills and Diffley 2014; Macheret and Halazonetis 2015). For example, increased expression or aberrant expression of the Myc oncogene activates p53, which results in apoptosis, protecting the cell from hyperproliferation. Oncogenes activate p53 by inducing ARF (Zindy et al. 1998; Eischen et al. 1999), which is an inhibitor of Mdm2 (Zhang et al. 1998; Weber et al. 1999). Mdm2 is the E3 ubiquitin ligase that binds and ubiquitinates p53, resulting in p53 degradation. Replication stress has recently been reported to cause chromosome instability in colon cancer cells (Burrell et al. 2013) and, thus, p53 activation would presumably prevent oncogene-induced chromosome instability. The p53-induced apoptosis that occurs upon oncogene dysregulation is a safety net to eliminate any cell that has unregulated growth (Fig. 1). Therefore, p53 activation prevents oncogene-induced cellular transformation, which occurs, in part, due to DNA damage.

\section{ANEUPLOIDY, POLYPLOIDY, AND TETRAPLOIDY}

Cell-cycle control is essential for maintaining stable genomes and preventing loss or gain of chromosomes. When p53 is inactivated, there is a loss of cell-cycle checkpoint control and the development of aneuploidy, polyploidy, and tetraploidy occurs (Fig. 2) (reviewed in Aylon and Oren 2011). Tumors harboring inactive p53 show an increase in tetraploidy, polyploidy, and/or aneuploidy (Deangelis et al. 1993; Ramel et al. 1995; Galipeau et al. 1996). Determining whether the inactivation of p53 and the alteration in ploidy were linked has taken many years, but it is now clear that they are. Data from genetically engineered mouse models has been essential to make this conclusion. For example, tumors from $p 53^{+/-}$mice that have deleted the wild-type allele had fivefold more chromosomal copy number alterations (increased and/or decreased), as determined by comparative genomic hybridization, than tumors that retained one allele of p53 (Venkatachalam et al. 1998). Additionally, $80 \%$ of the tumors from $p 53^{-/-}$ MMTV-ras transgenic mice were aneuploid, whereas only $30 \%$ of the tumors from control MMTV-ras transgenic mice showed aneuploidy (Hundley et al. 1997). Notably, inactivation or deletion of p53 causes a fairly rapid change in

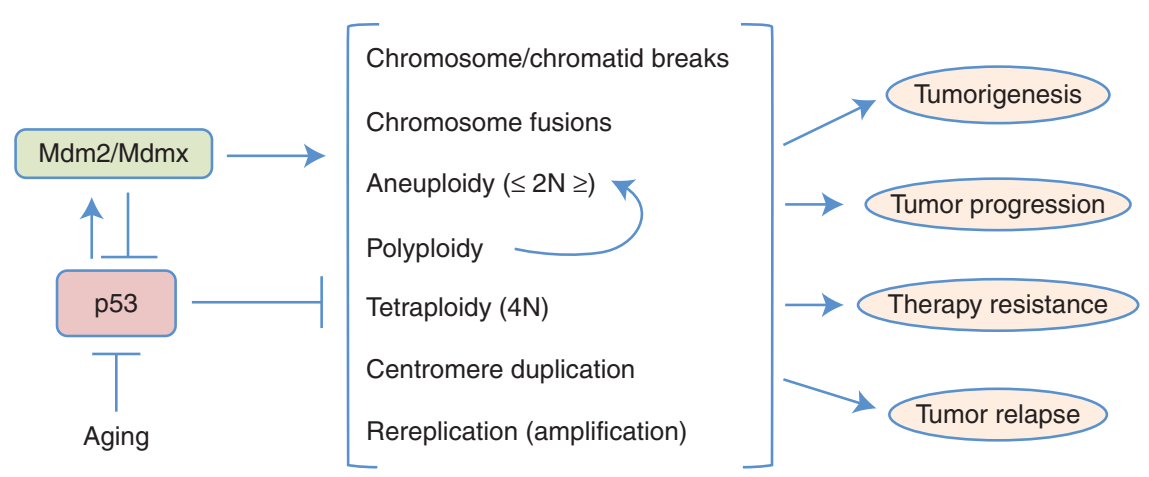

Figure 2. p53 inhibits, whereas Mdm2/Mdmx and aging induce, genome instability. Various forms of genome instability (listed in the center) can lead to increased cellular transformation potential and the other outcomes on the right. The role of $\mathrm{p} 53, \mathrm{Mdm} 2 / \mathrm{Mdmx}$, and aging are indicated. 
ploidy in untransformed cells in culture. Fibroblasts from $p 53^{-/-}$mice quickly become tetraploid after a few passages in culture (Livingstone et al. 1992; Harvey et al. 1993). Furthermore, loss of p53 is reported essential for the survival of aneuploid cells (Fujiwara et al. 2005; Thompson and Compton 2010; Vitale et al. 2010). These and other data strongly indicate that loss of functional p53 results in changes to ploidy regardless of the transformation status of the cell.

Investigations with separation of function mutants of $\mathrm{p} 53$ provided insight into which the downstream effect of p53 contributed to maintaining genome stability. Mice that were engineered to express a mutation in p53 (R172P named $p 53^{515 C}$ ) that disabled its apoptosis-inducing capabilities, but still allowed for at least partial cell-cycle-arrest function, provided insight into genomic instability caused by p53 inactivation. Lymphomas arising in $p 53^{R 172 P / R 172 P}$ mice are not aneuploid as tumors in p53-null mice are. Moreover, nontransformed mouse embryo fibroblasts (MEFs) from $p 53^{R 172 P / R 172 P}$ mice also retained a diploid genome (Liu et al. 2004). Thus, regulation of cell cycle appears responsible for maintaining genomic stability. In support of this concept, fibroblasts and tumors from $p 53^{R 172 P / R 172 P}$ mice that were also $p 21$-null showed increased genome instability (breaks and fusions). There was defective DNA-damage-induced cell-cycle arrest in MEFs from $p 53^{R 172 P / R 172 P} p 21$-null mice (Barboza et al. 2006). However, $p 21$ deletion alone has been shown to result in polyploidy (Mantel et al. 1999). Additionally, knockdown of another cell-cycle inhibitor, p16Ink4a, in $p 53^{R 172 P / R 172 P}$ MEFs also showed increased chromosome instability (Barboza et al. 2006). The other gene encoded in the p16 locus, p19Arf, was not tested in these assays. However, tumors from Arf-null mice are reported diploid, emphasizing that the effects on ploidy are independent of Arf (Kamijo et al. 1999). Overexpression of Mdm2, which negatively regulates $\mathrm{p} 53$, does not result in tetraploidization; this finding was difficult to understand until its p53-independent function in inhibiting DNA break repair was discovered (described below).
Aneuploidy can arise from chromosome missegregation during mitosis and, specifically, the presence of lagging chromosomes during anaphase (Compton 2011). Defects in the spindle assembly checkpoint (SAC) result in chromosome missegregation and aneuploidy ( $\mathrm{Li}$ et al. 2010; Thompson and Compton 2010). Chromosomes that do not segregate properly can result in a DNA double-strand break, which activates the DNA-damage response that includes p53 (Janssen et al. 2011). Loss of p53 is postulated to result in chromosomal translocations and aneuploidy in these circumstances (Li et al. 2010). Cells from several organs from p53-null mice show aneuploidy (Fukasawa et al. 1997), which is frequently referred to as chromosome instability (CIN), because the latter can cause the former. However, aneuploidy cells can have stable karyotypes, but cells with CIN do not. It has been determined that cells with CIN missegregate a chromosome one in every five cell divisions (Lengauer et al. 1997; Thompson and Compton 2008). Loss of p53 was shown to be essential for aneuploidy cell survival and proliferation (Fujiwara et al. 2005; Thompson and Compton 2010; Vitale et al. 2010). Moreover, loss of $\mathrm{p} 53$ accelerates aneuploidy-induced tumorigenesis ( $\mathrm{Li}$ et al. 2010). Polyploidy is thought to be a precursor to aneuploidy, and both can be present in cells that lack functional p53 (Ganem et al. 2007; Storchova and Kuffer 2008). In addition, overexpression of $\mathrm{Mdm} 2$ in the mammary gland of mice resulted in polyploidy whether p53 was present or not (Lundgren et al. 1997). This phenotype may be caused by $\mathrm{Mdm} 2$ inhibiting p53 when p53 is expressed, but it also may be caused by the p53-independent functions of $\mathrm{Mdm} 2$ (Figs. 1 and 2).

Multipolar mitoses result from centrosome amplification and these lead to lagging chromosomes and aneuploidy (Sluder and Nordberg 2004; Ganem et al. 2009). Centrosome duplication occurs with increased ploidy, but does not require it. A positive correlation between p53 inactivation and centrosome amplification in tumor cells has been observed (Carroll et al. 1999). MEFs lacking p53 contain multiple copies of centrosomes (Fukasawa et al. 1996), and 
amplification of centrosomes and abnormal mitotic spindles were observed in various tissues from p53-null mice (Fukasawa et al. 1997). Restoration of p53 in p53-null cells significantly corrects centrosome numbers (Tarapore et al. 2001). Cell-cycle proteins Cdk2 and Cdk4 are important for the centrosome cycle and are required for centrosome amplification in cells lacking p53, as deletion of $C d k 2$ or $C d k 4$ prevents centrosome duplication in p53-null mice (Adon et al. 2010). Moreover, deletion of $C d k 2$ or $C d k 4$ also decreased micronuclei formation in p53-null MEFs (Adon et al. 2010). Gadd45a, which is involved in $\mathrm{G}_{2} / \mathrm{M}$ progression, is a p53 target gene. Its loss leads to centrosome amplification and aneuploidy, but not an increase in tumorigenesis (Hollander et al. 1999; Wang et al. 1999). p53 has also been linked to centrosome duplication through its localization to centrosomes, but the mechanism for this is unknown (Shinmura et al. 2007).

Tetraploidy, 4N DNA content (Fig. 2), results from a bypass of mitosis, which can be caused by several poorly understood mechanisms during cell-cycle progression. Mitotic slippage (exit from mitosis without undergoing cytokinesis), impaired cytokinesis, and endoreduplication lead to tetraploidy. Loss of p53 induces tretraploidization, which is postulated to be caused by a loss of the so-called p53-mediated tetraploidy checkpoint in $\mathrm{G}_{1}$ that induces p21 and inhibits Rb phosphorylation (Andreassen et al. 2001). p53 has also been implicated in the mitotic spindle checkpoint. $p 53$-null fibroblasts fail to complete chromosome segregation following spindle inhibition and, instead, undergo multiple rounds of DNA synthesis. Additionally, tetraploid cells are present in p53-null mice (Cross et al. 1995; Notterman et al. 1998). Tetraploidy is also caused by endoreduplication, which is the replication of the genome without mitosis. Mdm2 overexpression has been shown to lead to endoreduplication in vivo, resulting in $4 \mathrm{~N}, 8 \mathrm{~N}$, and $16 \mathrm{~N}$ DNA content in the epithelial cells of mammary glands (Lundgren et al. 1997). p53 transcriptionally regulates mitotic regulators (i.e., AuroraA, Plk2, and Plk4; Fig. 1) and, thus, can impact mitosis in this manner as well (Kurinna et al. 2013).
Dysregulation of DNA replication factors can lead to rereplication (Fig. 2), replication origins firing more than once in one $\mathrm{S}$ phase, and this results in DNA damage and p53 activation. Rereplication differs from endoreduplication in that the entire genome is not replicated during rereplication. Gene amplification can result from rereplication. Functional p53 has been shown to be necessary to inhibit DNA rereplication (Vaziri et al. 2003).

Altered ploidy is hypothesized to contribute to tumorigenesis (Fig. 2) caused by loss of one or more tumor suppressors and/or gain of one or more oncogenes or cell-survival proteins. This may be due directly to the genes encoded in the lost or gained chromosome(s) and/or indirectly to changes in transcription or translation from proteins that mediate these processes or chromatin structure regulated by proteins involved in epigenetics. The result of altered ploidy can be cellular transformation, but this is not always the case. Although p53 inactivation leads to altered ploidy, which can increase transformation, it is not considered sufficient to induce transformation (Fujiwara et al. 2005).

\section{p73 CONTRIBUTES TO GENOME STABILITY}

The p53 family member, p73, shares some apoptosis-inducing and cell-cycle-blocking functions of p53 and has been linked to genomic instability. Deletion of $p 73$ results in developmental defects and death, but not the malignancy-inducing phenotype of $p 53$-null mice (Yang et al. 2000). However, mice lacking TAp73, a p73 isoform that contains the transactivation domain, do develop tumors (Tomasini et al. 2008). Knockdown of p73 or inhibition of its transcriptional function results in delays in completion of mitosis resulting in lagging chromosomes and the appearance of micronuclei and binucleated cells, indicating that p73 is important for mitotic exit (Merlo et al. 2005). MEFs lacking p73 undergo a p53-mediated senescence. Yet, MEFs null for both $p 73$ and $p 53$ have an increase in aneuploidy and polyploidy compared to cells just lacking p53. The alterations in ploidy were not caused by defects in centrosome duplication, SAC, or cytokinesis 
(Talos et al. 2007). MEFs or lung fibroblasts, but not thymocytes, from mice lacking the TAp73 isoform have a defective mitotic arrest and consequently have slightly increased aneuploidy following nocodazole treatment. Moreover, TAp73 ${ }^{-9}$ MEFs on a 3T3 protocol showed increased aneuploidy compared to wild-type controls ( Tomasini et al. 2008). Additionally, Mdm2 overexpression coupled with a loss of one or both alleles of $p 73$ in early passage MEFs increased chromosome and chromatid breaks and the number of metaphases with more than two abnormalities compared to either $M d m 2$ transgenic or deletion of $p 73$ alone (Riley et al. 2015). Together, the data suggest that p73 contributes to maintaining the genome, but works with p53 to accomplish this.

\section{Mdm2 AND Mdmx INDUCE GENOME INSTABILITY}

Alterations in the regulators of p53, Mdm2 and Mdmx, are also linked to genome instability (Figs. 1, 2). Mdm2 keeps p53 in check by binding to p53, inhibiting its transcriptional activity, and targeting it for degradation. Mdmx also regulates $\mathrm{p} 53$, but not through ubiquitination. Mdmx interacts with $\mathrm{Mdm} 2$ and thereby increases the ability of $\mathrm{Mdm} 2$ to ubiquitinate p53. Many human cancers overexpress Mdm2 and/or Mdmx (Eischen and Lozano 2014). The inhibition of p53 by increased levels of Mdm2 and Mdmx certainly dampens DNAdamage signaling and reduces the $\mathrm{p} 53$ response to DNA damage (Wang et al. 2008; Xiong et al. 2010). Moreover, overexpression of Mdm2 induced centrosome amplification, aberrant mitotic spindles, and significant aneuploidy in 3T3 cells (Carroll et al. 1999).

Although it is well established that Mdm2 regulates $\mathrm{p} 53$, in recent years it has also become clear that $\mathrm{Mdm} 2$ contributes to tumorigenesis through a p53-independent mechanism that impacts genome stability (Fig. 1) (Melo and Eischen 2012). We have determined that Mdm2 binds to Nbs1 of the MRN DNA repair complex (Alt et al. 2005; Bouska et al. 2008). The MRN complex responds to DNA breaks and signals to other proteins to facilitate break repair (Rein and Stracker 2014). The MRN complex is also essential to amplify ATM signaling (Shiloh and Ziv 2013). Binding of Mdm2 to Nbs1 delays DNA break repair in a p53-independent manner and results in increased chromosome and chromatid breaks and fusions. Data suggest that the early DNA-damage signal is delayed by increased levels of $\mathrm{Mdm} 2$, and that this results in DNA breaks remaining for longer periods of time in cells that overexpress Mdm2 (Alt et al. 2005; Bouska et al. 2008). Under conditions in which Mdm2 levels are elevated, there is an increase in chromosome and chromatid breaks and increased transformation potential in cells that lack functional p53 (Bouska et al. 2008). Notably, the E3 ubiquitin ligase activity of $\mathrm{Mdm} 2$ is not required to delay DNA break repair (Alt et al. 2005; Bouska et al. 2008).

Recently, we have reported that, similar to Mdm2, Mdmx can also impact DNA break repair (Carrillo et al. 2015a). Mdmx also associates with Nbs1 of the MRN complex. Elevated levels of Mdmx cause a blunting of the early DNAdamage signal resulting in a delay in DNA break repair (Fig. 1). There is an increase in genome instability in cells that have elevated levels of Mdmx, as measured by increased chromosome and chromatid breaks and transformation ability. Notably, the inhibition of DNA break repair by $\mathrm{Mdmx}$ was independent of Mdm2, as Mdmx was fully capable of delaying DNA break repair and the early DNA-damage signal in MEFs lacking Mdm2. Additionally, Mdmx lacking its RING domain was as effective at inhibiting DNA break repair as full-length Mdmx (Carrillo et al. 2015a). Therefore, both Mdm2 and Mdmx can impact genome stability by inhibiting p53 and the MRN complex.

Further evidence that Mdm2 and Mdmx contribute to genome instability came from experiments with mice genetically engineered to express reduced levels of $\mathrm{Mdm} 2$ or Mdmx. $M d m 2$ heterozygosity in Arf-null MEFs resulted in increased chromosomal stability with fewer chromosome and chromatid breaks and chromosome fusions compared to MEFs only lacking Arf (Wang et al. 2006). There were also delays in tumorigenesis with $\mathrm{Mdm} 2$ haploinsufficient mice and mice that were hypomor- 
phic for Mdm2 (Alt et al. 2003; Mendrysa et al. 2003; Wang et al. 2006). Reduced levels of Mdm2 inhibited tumorigenesis in mice lacking Arf, but not when $p 53$ was deleted, indicating that loss of $\mathrm{p} 53$ is dominant (Eischen and Boyd 2012). In contrast to Mdm2, loss of Mdmx in the context of a $p 53$ deletion results in increased genome instability. $M d m x^{-/-} p 53^{-/-}$MEFs have multipolar mitotic spindle formation and loss of chromosomes (Matijasevic et al. 2008a). It is thought that this increase in genome instability leads to tumorigenesis, as mice lacking both Mdmx and p53 have an accelerated rate of tumorigenesis compared to p53-null alone (Matijasevic et al. 2008b).

\section{MicroRNA (miRNA) AND p53}

Small noncoding RNA, such as miRNA, that regulate expression of genes and that target p53 are also likely to have a role in genome instability. For example, at least two dozen miRNA, of which miR-125b was the first shown, target $p 53$ and decrease p53 levels (Le et al. 2009). p53 also regulates the expression of miRNA that contribute to responding to DNA damage (Feng et al. 2011; Liao et al. 2014). For example, it is now well accepted that the miR-34 family is transcriptionally regulated by p 53 (Fig. 1) and is up-regulated following DNA damage or oncogenic stress (Chang et al. 2007; He et al. 2007; Tarasov et al. 2007). Recently, it was reported that many genes that are thought to be repressed by $\mathrm{p} 53$ are those that the miR-34 family target (Hunten et al. 2015). Although deletion of the miR-34 family in mice did not abrogate p53-mediated apoptosis or cell-cycle arrest (Concepcion et al. 2012), it and other miRNAs are reported to contribute to these p53-induced effects (He et al. 2007; Raver-Shapira et al. 2007; Hermeking 2012), which can also contribute to genome stability. miRNA processing has also been shown to be modulated by p53 (Suzuki et al. 2009). Because an inability to properly respond to DNA damage leads to genomic alterations, additional investigations are needed to determine whether and how significant of a role miRNA has in p53mediated genome stability.

\section{AGING AND THE p53 PATHWAY}

Aging is associated with increased genome instability. Reduced ATM activation and p53 function with age (Fig. 2) contributes to reduced apoptosis and DNA repair and increased chromosome instability and tumorigenesis (Feng et al. 2007). A recent study shows a positive association between p53 mutations and age-related cancers worldwide (Richardson 2013). The investigators postulate that p53 mutations may account for $25 \%$ of the age-related increase in cancers in the United States and $30 \%$ in Japan. Although this study did not take into consideration genome instability or other factors, it does highlight the importance of maintaining functional p53 throughout the life span of a person.

Aging itself causes an increase in genome stability with elevated chromatid and chromosome breaks, chromosome fusions, and aneuploidy. However, elevated levels (threefold to fourfold) of $\mathrm{Mdm} 2$ in $M d m 2$ transgenic mice are responsible for inducing both structural and numerical chromosomal alterations at younger ages before the development of overt cancer. $M d m 2$ transgenic mice had a significantly increased frequency of cells with chromosome and chromatid breaks, chromosome fusions, aneuploidy, and polyploidy. Severe chromosome abnormities, such as ringed chromosomes and triradial chromosomes, were observed only in $M d m 2$ transgenic mice and not wild-type littermates. Moreover, splenocytes with $\mathrm{Mdm} 2$ overexpression had increased gains in one or more chromosomes, but had a similar rate of chromosome loss compared to wildtype littermates (Lushnikova et al. 2011). Therefore, increased levels of $\mathrm{Mdm} 2$ coupled with aging significantly increased the development of chromosome aberrations.

\section{p53 INACTIVATION IN CANCER}

One of the most frequent abnormalities identified in human cancers is mutation of p53, and virtually all human cancers have inactivated the p53 pathway (see Wasylishen and Lozano 2015). This occurs because cancers require unregulated growth and p53 will not allow this. Moreover, 
loss of p53 will confer resistance to apoptotic stimuli, allowing cells with genomic alterations to survive when they would have otherwise undergone apoptosis. Cells from people with $\mathrm{Li}-$ Fraumeni syndrome that have germline mutations in $p 53$ have increased genomic instability with increased telomere attrition and aneuploidy (Bischoff et al. 1990; Tabori et al. 2007). LiFraumeni patients have an increased frequency of developing early-onset cancers and multiple cancers during their lifetime (Malkin et al. 1990; Srivastava et al. 1990). Additionally, humans with the single-nucleotide polymorphism in Mdm2 (SNP309), which results in increased expression of Mdm2, can also have elevated rates of cancers (Eischen and Lozano 2014).

Most, and likely all, human cancers have some form of genome instability. However, there is debate whether genome instability precedes tumorigenesis or is a consequence of it. Certainly, cells have to lose cell-cycle control and be resistant to some apoptotic signals to become a cancer cell. Aneuploidy by itself has been shown to both induce and inhibit tumorigenesis depending on the circumstances (Sotillo et al. 2007; Weaver et al. 2007), indicating that it is likely insufficient alone. Moreover, once the tumor develops, aneuploidy can drive tumor evolution (Nowell 1976; Thompson et al. 2010). Mutation of p53 is thought to contribute to the early stages of tumor development for some cancers and to be an intermediate stage or later stage of other cancers (Rivlin et al. 2011). Mice engineered to express increased levels of p53 (three copies, super p53 mice) show an increased p21 induction, more apoptosis to $\gamma$ radiation, and are resistant to tumorigenesis (Garcia-Cao et al. 2002). It is unknown whether their genomes were more stable. Thymocytes from mice with the $\mathrm{p} 53$ mutation, $\mathrm{p} 53^{\mathrm{R} 248 \mathrm{~W}}$, have increased interchromosomal translocations before tumor development (Song et al. 2007). Mdm2 transgenic mice have increased genome instability before cancer could be detected, suggesting that genome instability preceded tumor development (Lushnikova et al. 2011). Certainly, if mutation of p53 does not occur early in tumor development, chemotherapy is postulated to either induce $\mathrm{p} 53$ mutations or has recently been shown to allow for rare p53 mutant cells to expand (Wong et al. 2015). Aneuploidy and chromosome instability are associated with worse patient outcomes, metastasis, resistance to chemotherapy, and relapse (Fig. 2) (Carter et al. 2006; Walther et al. 2008; Swanton et al. 2009; Sotillo et al. 2010; Bakhoum et al. 2011; Lee et al. 2011; Smid et al. 2011; McGranahan et al. 2012).

\section{CONCLUDING REMARKS}

Genome instability and cancer are intimately linked. With p53 being a significant regulator of genome stability and at least half of all human cancers directly inactivating p53, cancers have unstable genomes. The advantage for the cancer to have an unstable genome is the selection for growth and survival advantages to withstand environments that are less than hospitable to cancer cells. It is clear that p53 has an integral role in maintaining genomes that without it, genome instability ensues. The link that has been made between loss of $\mathrm{p} 53$ or the p53 pathway and emergence of genome instability is firmly established, but it is not completely understood by cancer biologists.

However, increased understanding of p53 function and mechanistic insights into how it maintains genome stability should lead to better therapeutics for cancer treatment. This knowledge can be used in designing drugs that cooperate with genome instability to induce a synthetic lethality. For example, cancers that have inactivated p53 can be resistant to agents that induce DNA damage, because loss of p53 depresses the DNA-damage response signal and also confers resistance to apoptosis. However, recently, new approaches to capitalize on the genome instability of cancer cells for treatment are being tested. For example, pharmacologically increasing Mdm2 levels with Nutlin in ovarian carcinoma cells that lack functional p53 causes a delay in DNA break repair that results in increased sensitivity to DNA-damage agents, such as cisplatin and etoposide (Carrillo et al. 2015b). Topoisomerase II inhibitors were shown to cooperate with Nutlin in pancreatic cancer cells that lacked functional p53 (Conradt 


\section{C.M. Eischen}

et al. 2012). Recently, Nutlin increased the effectiveness of carboplatin for a particularly aggressive subtype of breast cancer that harbored mutant $\mathrm{p} 53$, resulting in increased cell death and reduced metastasis (Tonsing-Carter et al. 2015). Therefore, using genome instability against the cancer may be an effective therapeutic strategy that certainly warrants further investigation.

\section{ACKNOWLEDGMENTS}

I thank members of the Eischen laboratory for reviewing this manuscript. C.M.E. is supported by R01 CA181204.

\section{REFERENCES}

${ }^{*}$ Reference is also in this collection.

Adon AM, Zeng X, Harrison MK, Sannem S, Kiyokawa H Kaldis P, Saavedra HI. 2010. Cdk2 and Cdk4 regulate the centrosome cycle and are critical mediators of centrosome amplification in p53-null cells. Mol Cell Biol 30: 694-710.

Aguilera A, Garcia-Muse T. 2013. Causes of genome instability. Annu Rev Genet 47: 1-32.

Alt JR, Greiner T, Cleveland JL, Eischen CM. 2003. Mdm2 haplo-insufficiency profoundly inhibits Myc-induced lymphomagenesis. EMBO J 22: 1442-1450.

Alt JR, Bouska A, Fernandez MR, Cerny RL, Xiao H, Eischen CM. 2005. Mdm2 binds to Nbs1 at sites of DNA damage and regulates double strand break repair. J Biol Chem 280: $18771-18781$.

Andreassen PR, Lohez OD, Lacroix FB, Margolis RL. 2001 Tetraploid state induces p53-dependent arrest of nontransformed mammalian cells in $\mathrm{G}_{1}$. Mol Biol Cell 12: 1315-1328.

Aylon Y, Oren M. 2011. p53: Guardian of ploidy. Mol Oncol 5: 315-323.

Bakhoum SF, Danilova OV, Kaur P, Levy NB, Compton DA. 2011. Chromosomal instability substantiates poor prognosis in patients with diffuse large B-cell lymphoma. Clin Cancer Res 17: 7704-7711.

Barboza JA, Liu G, Ju Z, El-Naggar AK, Lozano G. 2006. p21 delays tumor onset by preservation of chromosomal stability. Proc Natl Acad Sci 103: 19842-19847.

Beishline K, Azizkhan-Clifford J. 2014. Interplay between the cell cycle and double-strand break response in mammalian cells. Methods Mol Biol 1170: 41-59.

Bischoff FZ, Yim SO, Pathak S, Grant G, Siciliano MJ, Giovanella BC, Strong LC, Tainsky MA. 1990. Spontaneous abnormalities in normal fibroblasts from patients with Li-Fraumeni cancer syndrome: Aneuploidy and immortalization. Cancer Res 50: 7979-7984.

Bouska A, Lushnikova T, Plaza S, Eischen CM. 2008. Mdm2 promotes genetic instability and transformation independent of p53. Mol Cell Biol 28: 4862-4874.
Brown JP, Wei W, Sedivy JM. 1997. Bypass of senescence after disruption of $\mathrm{p} 21^{C I P 1 / W A F 1}$ gene in normal diploid human fibroblasts. Science 277: 831-834.

Burrell RA, McClelland SE, Endesfelder D, Groth P, Weller MC, Shaikh N, Domingo E, Kanu N, Dewhurst SM, Gronroos E, et al. 2013. Replication stress links structural and numerical cancer chromosomal instability. Nature 494: $492-496$.

Campisi J. 2005. Senescent cells, tumor suppression, and organismal aging: Good citizens, bad neighbors. Cell 120: $513-522$.

Carrillo AM, Bouska A, Arrate MP, Eischen CM. 2015a Mdmx promotes genomic instability independent of p53 and Mdm2. Oncogene 34: 846-856.

Carrillo AM, Hicks M, Khabele D, Eischen CM. 2015b. Pharmacologically increasing $\mathrm{Mdm} 2$ inhibits DNA repair and cooperates with genotoxic agents to kill p53 inactivated ovarian cancer cells. Mol Cancer Res 13: 11971205.

Carroll PE, Okuda M, Horn HF, Biddinger P, Stambrook PJ, Gleich LL, Li YQ, Tarapore P, Fukasawa K. 1999. Centrosome hyperamplification in human cancer: Chromosome instability induced by p 53 mutation and/or Mdm2 overexpression. Oncogene 18: 1935-1944.

Carter SL, Eklund AC, Kohane IS, Harris LN, Szallasi Z. 2006. A signature of chromosomal instability inferred from gene expression profiles predicts clinical outcome in multiple human cancers. Nat Genet 38: 1043-1048.

Carvajal LA, Manfredi JJ. 2013. Another fork in the roadLife or death decisions by the tumour suppressor p53. EMBO Rep 14: 414-421.

Chang TC, Wentzel EA, Kent OA, Ramachandran K, Mullendore M, Lee KH, Feldmann G, Yamakuchi M, Ferlito M, Lowenstein CJ, et al. 2007. Transactivation of miR-34a by 53 broadly influences gene expression and promotes apoptosis. Mol Cell 26: 745-752.

Chipuk JE, Kuwana T, Bouchier-Hayes L, Droin NM, Newmeyer DD, Schuler M, Green DR. 2004. Direct activation of Bax by p53 mediates mitochondrial membrane permeabilization and apoptosis. Science 303: 1010-1014.

Compton DA. 2011. Mechanisms of aneuploidy. Curr Opin Cell Biol 23: 109-113.

Concepcion CP, Han YC, Mu P, Bonetti C, Yao E, D’Andrea A, Vidigal JA, Maughan WP, Ogrodowski P, Ventura A. 2012. Intact p53-dependent responses in miR-34-deficient mice. PLoS Genet 8: e1002797.

Conradt L, Henrich A, Wirth M, Reichert M, Lesina M, Algul H, Schmid RM, Kramer OH, Saur D, Schneider G. 2012. Mdm2 inhibitors synergize with topoisomerase II inhibitors to induce p53-independent pancreatic cancer cell death. Int J Cancer 132: 2248-2257.

Crighton D, Wilkinson S, O’Prey J, Syed N, Smith P, Harrison PR, Gasco M, Garrone O, Crook T, Ryan KM. 2006. DRAM, a p53-induced modulator of autophagy, is critical for apoptosis. Cell 126: 121-134.

Cross SM, Sanchez CA, Morgan CA, Schimke MK, Ramel S, Idzerda RL, Raskind WH, Reid BJ. 1995. A p53-dependent mouse spindle checkpoint. Science 267: 1353-1356.

Czabotar PE, Lessene G, Strasser A, Adams JM. 2014. Control of apoptosis by the BCL-2 protein family: Implica- 
tions for physiology and therapy. Nat Rev Mol Cell Biol 15: 49-63.

Deangelis P, Stokke T, Smedshammer L, Lothe R, Meling G, Rofstad M, Chen Y, Clausen O. 1993. P53 expression is associated with a high-degree of tumor DNA aneuploidy and incidence of p53 gene mutation, and is localized to the aneuploid component in colorectal carcinomas. Int J Oncol 3: 305-312.

de Stanchina E, Querido E, Narita M, Davuluri RV, Pandolfi PP, Ferbeyre G, Lowe SW. 2004. PML is a direct p53 target that modulates p53 effector functions. Mol Cell 13: 523 535.

Eischen CM, Boyd K. 2012. Decreased Mdm2 expression inhibits tumor development and extends survival independent of Arf and dependent on p53. PLoS ONE 7: e46148.

Eischen CM, Lozano G. 2014. The Mdm network and its regulation of p53 activities: A rheostat of cancer risk. Hum Mutat 35: 728-737.

Eischen CM, Weber JD, Roussel MF, Sherr CJ, Cleveland JL. 1999. Disruption of the ARF-Mdm2-p53 tumor suppressor pathway in Myc-induced lymphomagenesis. Genes Dev 13: 2658-2669.

el-Deiry WS, Tokino T, Velculescu VE, Levy DB, Parsons R, Trent JM, Lin D, Mercer WE, Kinzler KW, Vogelstein B. 1993. WAF1, a potential mediator of p53 tumor suppression. Cell 75: 817-825.

Ewen ME, Oliver CJ, Sluss HK, Miller SJ, Peeper DS. 1995. p53-dependent repression of CDK4 translation in TGF$\beta$-induced $G_{1}$ cell-cycle arrest. Genes Dev 9: 204-217.

Feng Z, Hu W, Teresky AK, Hernando E, Cordon-Cardo C, Levine AJ. 2007. Declining p53 function in the aging process: A possible mechanism for the increased tumor incidence in older populations. Proc Natl Acad Sci 104: $16633-16638$.

Feng Z, Zhang C, Wu R, Hu W. 2011. Tumor suppressor p53 meets microRNAs. J Mol Cell Biol 3: 44-50.

Fujiwara T, Bandi M, Nitta M, Ivanova EV, Bronson RT, Pellman D. 2005. Cytokinesis failure generating tetraploids promotes tumorigenesis in p53-null cells. Nature 437: 1043-1047.

Fukasawa K, Choi T, Kuriyama R, Rulong S, Vande Woude GF. 1996. Abnormal centrosome amplification in the absence of p53. Science 271: 1744-1747.

Fukasawa K, Wiener F, Vande Woude GF, Mai S. 1997. Genomic instability and apoptosis are frequent in p53 deficient young mice. Oncogene 15: 1295-1302.

Galipeau PC, Cowan DS, Sanchez CA, Barrett MT, Emond MJ, Levine DS, Rabinovitch PS, Reid BJ. 1996. 17p ( p53) allelic losses, $4 \mathrm{~N}\left(\mathrm{G}_{2} /\right.$ tetraploid) populations, and progression to aneuploidy in Barrett's esophagus. Proc Natl Acad Sci 93: 7081-7084.

Galluzzi L, Morselli E, Kepp O, Vitale I, Pinti M, Kroemer G. 2011. Mitochondrial liaisons of p53. Antioxid Redox Signal 15: 1691-1714.

Ganem NJ, Storchova Z, Pellman D. 2007. Tetraploidy, aneuploidy and cancer. Curr Opin Genet Dev 17: 157-162.

Ganem NJ, Godinho SA, Pellman D. 2009. A mechanism linking extra centrosomes to chromosomal instability. Nature 460: 278-282.
Gannon HS, Woda BA, Jones SN. 2012. ATM phosphorylation of Mdm2 Ser394 regulates the amplitude and duration of the DNA damage response in mice. Cancer Cell 21: $668-679$

Garcia-Cao I, Garcia-Cao M, Martin-Caballero J, Criado LM, Klatt P, Flores JM, Weill JC, Blasco MA, Serrano M. 2002. "Super p53" mice exhibit enhanced DNA damage response, are tumor resistant and age normally. EMBO J 21: 6225-6235.

Hanahan D, Weinberg RA. 2011. Hallmarks of cancer: The next generation. Cell 144: 646-674.

Harper JW, Adami GR, Wei N, Keyomarsi K, Elledge SJ. 1993. The p21 Cdk-interacting protein Cip1 is a potent inhibitor of $\mathrm{G}_{1}$ cyclin-dependent kinases. Cell 75: 805816.

Harvey M, Sands AT, Weiss RS, Hegi ME, Wiseman RW, Pantazis P, Giovanella BC, Tainsky MA, Bradley A, Donehower LA. 1993. In vitro growth characteristics of embryo fibroblasts isolated from p53-deficient mice. Oncogene 8: 2457-2467.

He L, He X, Lim LP, de Stanchina E, Xuan Z, Liang Y, Xue W, Zender L, Magnus J, Ridzon D, et al. 2007. A microRNA component of the p53 tumour suppressor network. $\mathrm{Na}$ ture 447: 1130-1134.

Hermeking H. 2012. MicroRNAs in the p53 network: Micromanagement of tumour suppression. Nat Rev Cancer 12: $613-626$.

Hills SA, Diffley JF. 2014. DNA replication and oncogeneinduced replicative stress. Curr Biol 24: R435-R444.

Hollander MC, Sheikh MS, Bulavin DV, Lundgren K, Augeri-Henmueller L, Shehee R, Molinaro TA, Kim KE, Tolosa E, Ashwell JD, et al. 1999. Genomic instability in Gadd45a-deficient mice. Nat Genet 23: 176-184.

Hundley JE, Koester SK, Troyer DA, Hilsenbeck SG, Subler MA, Windle JJ. 1997. Increased tumor proliferation and genomic instability without decreased apoptosis in MMTV-ras mice deficient in p53. Mol Cell Biol 17: $723-731$.

Hunten S, Kaller M, Drepper F, Oeljeklaus S, Bonfert T, Erhard F, Dueck A, Eichner N, Friedel CC, Meister G, et al. 2015. p53-regulated networks of protein, mRNA, miRNA and IncRNA expression revealed by integrated pSILAC and NGS analyses. Mol Cell Proteomics 14: 2609-2629.

Janssen A, van der Burg M, Szuhai K, Kops GJ, Medema RH. 2011. Chromosome segregation errors as a cause of DNA damage and structural chromosome aberrations. Science 333: $1895-1898$.

Kamijo T, Bodner S, van de Kamp E, Randle DH, Sherr CJ. 1999. Tumor spectrum in ARF-deficient mice. Cancer Res 59: 2217-2222.

Kortlever RM, Higgins PJ, Bernards R. 2006. Plasminogen activator inhibitor-1 is a critical downstream target of p53 in the induction of replicative senescence. Nat Cell Biol 8: 877-884

Kurinna S, Stratton SA, Coban Z, Schumacher JM, Grompe M, Duncan AW, Barton MC. 2013. p53 regulates a mitotic transcription program and determines ploidy in normal mouse liver. Hepatology 57: 2004-2013.

Lavin MF, Shiloh Y. 1997. The genetic defect in ataxia-telangiectasia. Annu Rev Immunol 15: 177-202. 


\section{C.M. Eischen}

Lawrence MS, Stojanov P, Polak P, Kryukov GV, Cibulskis K, Sivachenko A, Carter SL, Stewart C, Mermel CH, Roberts SA, et al. 2013. Mutational heterogeneity in cancer and the search for new cancer-associated genes. Nature 499: 214-218.

Le MT, Teh C, Shyh-Chang N, Xie H, Zhou B, Korzh V, Lodish HF, Lim B. 2009. MicroRNA-125b is a novel negative regulator of p53. Genes Dev 23: 862-876.

Lee AJ, Endesfelder D, Rowan AJ, Walther A, Birkbak NJ, Futreal PA, Downward J, Szallasi Z, Tomlinson IP, Howell M, et al. 2011. Chromosomal instability confers intrinsic multidrug resistance. Cancer Res 71: 1858-1870.

Lengauer C, Kinzler KW, Vogelstein B. 1997. Genetic instability in colorectal cancers. Nature 386: 623-627.

Lengauer C, Kinzler KW, Vogelstein B. 1998. Genetic instabilities in human cancers. Nature 396: 643-649.

Li M, Fang X, Baker DJ, Guo L, Gao X, Wei Z, Han S, van Deursen JM, Zhang P. 2010. The ATM-p53 pathway suppresses aneuploidy-induced tumorigenesis. Proc Natl Acad Sci 107: 14188-14193.

Liao JM, Cao B, Zhou X, Lu H. 2014. New insights into p53 functions through its target microRNAs. J Mol Cell Biol 6: 206-213.

Liu G, Parant JM, Lang G, Chau P, Chavez-Reyes A, El-Naggar AK, Multani A, Chang S, Lozano G. 2004. Chromosome stability, in the absence of apoptosis, is critical for suppression of tumorigenesis in Trp53 mutant mice. Nat Genet 36: 63-68.

Livingstone LR, White A, Sprouse J, Livanos E, Jacks T, Tlsty TD. 1992. Altered cell cycle arrest and gene amplification potential accompany loss of wild-type p53. Cell 70: 923 935.

Lundgren K, Montes de Oca Luna R, McNeill YB, Emerick EP, Spencer B, Barfield CR, Lozano G, Rosenberg MP, Finlay CA. 1997. Targeted expression of MDM2 uncouples $\mathrm{S}$ phase from mitosis and inhibits mammary gland development independent of p53. Genes Dev 11: $714-$ 725 .

Lushnikova T, Bouska A, Odvody J, Dupont WD, Eischen CM. 2011. Aging mice have increased chromosome instability that is exacerbated by elevated $\mathrm{Mdm} 2$ expression. Oncogene 30: 4622-4631.

Macheret M, Halazonetis TD. 2015. DNA replication stress as a hallmark of cancer. Annu Rev Pathol 10: 425-448.

Malkin D, Li FP, Strong LC, Fraumeni JF Jr, Nelson CE, Kim DH, Kassel J, Gryka MA, Bischoff FZ, Tainsky MA, et al. 1990. Germ line p53 mutations in a familial syndrome of breast cancer, sarcomas, and other neoplasms. Science 250: $1233-1238$.

Mantel C, Braun SE, Reid S, Henegariu O, Liu L, Hangoc G, Broxmeyer HE. 1999. p2 $1^{\text {cip-1/waf- } 1}$ deficiency causes deformed nuclear architecture, centriole overduplication, polyploidy, and relaxed microtubule damage checkpoints in human hematopoietic cells. Blood 93: 13901398.

Matijasevic Z, Krzywicka-Racka A, Sluder G, Jones SN. 2008a. MdmX regulates transformation and chromosomal stability in p53-deficient cells. Cell Cycle 7: 2967-2973.

Matijasevic Z, Steinman HA, Hoover K, Jones SN. 2008b. $\mathrm{MdmX}$ promotes bipolar mitosis to suppress transforma- tion and tumorigenesis in p53-deficient cells and mice. Mol Cell Biol 28: 1265-1273.

McGranahan N, Burrell RA, Endesfelder D, Novelli MR, Swanton C. 2012. Cancer chromosomal instability: Therapeutic and diagnostic challenges. EMBO Rep 13: 528 538.

Melo AN, Eischen CM. 2012. Protecting the genome from Mdm2 and Mdmx. Genes Cancer 3: 283-290.

Mendrysa SM, McElwee MK, Michalowski J, O’Leary KA, Young KM, Perry ME. 2003. Mdm2 is critical for inhibition of p53 during lymphopoiesis and the response to ionizing irradiation. Mol Cell Biol 23: 462-472.

Merlo P, Fulco M, Costanzo A, Mangiacasale R, Strano S, Blandino G, Taya Y, Lavia P, Levrero M. 2005. A role of p73 in mitotic exit. J Biol Chem 280: 30354-30360.

Mihara M, Erster S, Zaika A, Petrenko O, Chittenden T, Pancoska P, Moll UM. 2003. p53 has a direct apoptogenic role at the mitochondria. Mol Cell 11: 577-590.

Miyashita T, Reed JC. 1995. Tumor suppressor p53 is a direct transcriptional activator of the human bax gene. Cell 80: 293-299.

Nakano K, Vousden KH. 2001. PUMA, a novel proapoptotic gene, is induced by p53. Mol Cell 7: 683-694.

Negrini S, Gorgoulis VG, Halazonetis TD. 2010. Genomic instability-An evolving hallmark of cancer. Nat Rev Mol Cell Biol 11: 220-228.

Notterman D, Young S, Wainger B, Levine AJ. 1998. Prevention of mammalian DNA reduplication, following the release from the mitotic spindle checkpoint, requires p53 protein, but not $\mathrm{p} 53$-mediated transcriptional activity. Oncogene 17: 2743-2751.

Nowell PC. 1976. The clonal evolution of tumor cell populations. Science 194: 23-28.

Oda E, Ohki R, Murasawa H, Nemoto J, Shibue T, Yamashita T, Tokino T, Taniguchi T, Tanaka N. 2000. Noxa, a BH3only member of the Bcl-2 family and candidate mediator of p53-induced apoptosis. Science 288: 1053-1058.

Pantoja C, Serrano M. 1999. Murine fibroblasts lacking p21 undergo senescence and are resistant to transformation by oncogenic Ras. Oncogene 18: 4974-4982.

Ramel S, Sanchez CA, Schimke MK, Neshat K, Cross SM, Raskind WH, Reid BJ. 1995. Inactivation of p53 and the development of tetraploidy in the elastase-SV40 T antigen transgenic mouse pancreas. Pancreas 11: 213-222.

Raver-Shapira N, Marciano E, Meiri E, Spector Y, Rosenfeld N, Moskovits N, Bentwich Z, Oren M. 2007. Transcriptional activation of miR-34a contributes to p53-mediated apoptosis. Mol Cell 26: 731-743.

Reed SM, Quelle DE. 2014. p53 acetylation: Regulation and consequences. Cancers 7: 30-69.

Rein K, Stracker TH. 2014. The MRE11 complex: An important source of stress relief. Exp Cell Res 329: 162-169.

Richardson RB. 2013. p53 mutations associated with agingrelated rise in cancer incidence rates. Cell Cycle 12: $2468-$ 2478.

Riley MF, You MJ, Multani AS, Lozano G. 2015. Mdm2 overexpression and $p 73$ loss exacerbate genomic instability and dampen apoptosis, resulting in B-cell lymphoma. Oncogene doi: 10.1038/onc.2015.88. 
Rivlin N, Brosh R, Oren M, Rotter V. 2011. Mutations in the p53 tumor suppressor gene: Important milestones at the various steps of tumorigenesis. Genes Cancer 2: 466-474.

Serrano M, Lin AW, McCurrach ME, Beach D, Lowe SW. 1997. Oncogenic ras provokes premature cell senescence associated with accumulation of p53 and p16INK4a. Cell 88: $593-602$.

Shieh SY, Ikeda M, Taya Y, Prives C. 1997. DNA damageinduced phosphorylation of $\mathrm{p} 53$ alleviates inhibition by MDM2. Cell 91: 325-334.

Shiloh Y, Ziv Y. 2013. The ATM protein kinase: Regulating the cellular response to genotoxic stress, and more. Nat Rev Mol Cell Biol 14: 197-210.

Shinmura K, Bennett RA, Tarapore P, Fukasawa K. 2007. Direct evidence for the role of centrosomally localized p53 in the regulation of centrosome duplication. Oncogene 26: 2939-2944.

Sluder G, Nordberg JJ. 2004. The good, the bad and the ugly: The practical consequences of centrosome amplification. Curr Opin Cell Biol 16: 49-54.

Smid M, Hoes M, Sieuwerts AM, Sleijfer S, Zhang Y, Wang Y, Foekens JA, Martens JW. 2011. Patterns and incidence of chromosomal instability and their prognostic relevance in breast cancer subtypes. Breast Cancer Res Treat 128: 23-30.

Song H, Hollstein M, Xu Y. 2007. p53 gain-of-function cancer mutants induce genetic instability by inactivating ATM. Nat Cell Biol 9: 573-580.

Sotillo R, Hernando E, Diaz-Rodriguez E, Teruya-Feldstein J, Cordon-Cardo C, Lowe SW, Benezra R. 2007. Mad2 overexpression promotes aneuploidy and tumorigenesis in mice. Cancer Cell 11: 9-23.

Sotillo R, Schvartzman JM, Socci ND, Benezra R. 2010. Mad2-induced chromosome instability leads to lung tumour relapse after oncogene withdrawal. Nature 464: 436-440.

Srivastava S, Zou ZQ, Pirollo K, Blattner W, Chang EH. 1990. Germ-line transmission of a mutated $p 53$ gene in a cancer-prone family with $\mathrm{Li}-\mathrm{Fraumeni}$ syndrome. $\mathrm{Na}$ ture 348: 747-749.

Storchova Z, Kuffer C. 2008. The consequences of tetraploidy and aneuploidy. J Cell Sci 121: 3859-3866.

Suzuki HI, Yamagata K, Sugimoto K, Iwamoto T, Kato S, Miyazono K. 2009. Modulation of microRNA processing by p53. Nature 460: $529-533$.

Swanton C, Nicke B, Schuett M, Eklund AC, Ng C, Li Q, Hardcastle T, Lee A, Roy R, East P, et al. 2009. Chromosomal instability determines taxane response. Proc Natl Acad Sci 106: 8671-8676.

Tabori U, Nanda S, Druker H, Lees J, Malkin D. 2007. Younger age of cancer initiation is associated with shorter telomere length in $\mathrm{Li}$-Fraumeni syndrome. Cancer Res 67: 1415-1418.

Talos F, Nemajerova A, Flores ER, Petrenko O, Moll UM. 2007. p73 suppresses polyploidy and aneuploidy in the absence of functional p53. Mol Cell 27: 647-659.

Tarapore P, Horn HF, Tokuyama Y, Fukasawa K. 2001. Direct regulation of the centrosome duplication cycle by the p53-p21 Waf1/Cip1 pathway. Oncogene 20: 3173-3184.

Tarasov V, Jung P, Verdoodt B, Lodygin D, Epanchintsev A, Menssen A, Meister G, Hermeking H. 2007. Differential regulation of microRNAs by p53 revealed by massively parallel sequencing: miR-34a is a p53 target that induces apoptosis and $\mathrm{G}_{1}$ arrest. Cell Cycle 6: 1586-1593.

Thompson SL, Compton DA. 2008. Examining the link between chromosomal instability and aneuploidy in human cells. J Cell Biol 180: 665-672.

Thompson SL, Compton DA. 2010. Proliferation of aneuploid human cells is limited by a p53-dependent mechanism. J Cell Biol 188: 369-381.

Thompson SL, Bakhoum SF, Compton DA. 2010. Mechanisms of chromosomal instability. Curr Biol 20: R285R295.

Tomasini R, Tsuchihara K, Wilhelm M, Fujitani M, Rufini A, Cheung CC, Khan F, Itie-Youten A, Wakeham A, Tsao MS, et al. 2008. TAp73 knockout shows genomic instability with infertility and tumor suppressor functions. Genes Dev 22: 2677-2691.

Tonsing-Carter E, Bailey BJ, Sinn AL, Peterson KM, Spragins TK, Silver JM, Wang H, Saadatzadeh MR, Ding J, Sprouse AA, et al. 2015. Potentiation of carboplatin-mediated DNA damage by the Mdm2 modulator Nutlin-3a in a humanized orthotopic breast-to-lung metastatic model. Mol Cancer Ther 14: 2850-2863.

Vaseva AV, Marchenko ND, Ji K, Tsirka SE, Holzmann S, Moll UM. 2012. p53 opens the mitochondrial permeability transition pore to trigger necrosis. Cell 149: 1536-1548.

Vaziri C, Saxena S, Jeon Y, Lee C, Murata K, Machida Y, Wagle N, Hwang DS, Dutta A. 2003. A p53-dependent checkpoint pathway prevents rereplication. Mol Cell 11: 997-1008.

Venkatachalam S, Shi YP, Jones SN, Vogel H, Bradley A, Pinkel D, Donehower LA. 1998. Retention of wild-type p53 in tumors from p53 heterozygous mice: Reduction of p53 dosage can promote cancer formation. $E M B O J$ 17: 4657-4667.

Vitale I, Senovilla L, Jemaa M, Michaud M, Galluzzi L, Kepp O, Nanty L, Criollo A, Rello-Varona S, Manic G, et al. 2010. Multipolar mitosis of tetraploid cells: Inhibition by p53 and dependency on Mos. EMBO J 29: 1272-1284.

Walther A, Houlston R, Tomlinson I. 2008. Association between chromosomal instability and prognosis in colorectal cancer: A meta-analysis. Gut 57: 941-950.

Wang XW, Zhan Q, Coursen JD, Khan MA, Kontny HU, Yu L, Hollander MC, O'Connor PM, Fornace AJ Jr, Harris CC. 1999. GADD45 induction of a $\mathrm{G}_{2} / \mathrm{M}$ cell-cycle checkpoint. Proc Natl Acad Sci 96: 3706-3711.

Wang P, Greiner TC, Lushnikova T, Eischen CM. 2006. Decreased $\mathrm{Mdm} 2$ expression inhibits tumor development induced by loss of ARF. Oncogene 25: 3708-3718.

Wang P, Lushnikova T, Odvody J, Greiner TC, Jones SN, Eischen CM. 2008. Elevated Mdm2 expression induces chromosomal instability and confers a survival and growth advantage to B cells. Oncogene 27: 1590-1598.

* Wasylishen AR, Lozano G. 2015. Attenuating the p53 pathway in human cancers: Many means to the same end. Cold Spring Harb Perspect Med doi: 10.1101/cshper spect.a026211.

Weaver BA, Silk AD, Montagna C, Verdier-Pinard P, Cleveland DW. 2007. Aneuploidy acts both oncogenically and as a tumor suppressor. Cancer Cell 11: 25-36. 


\section{C.M. Eischen}

Weber JD, Taylor LJ, Roussel MF, Sherr CJ, Bar-Sagi D. 1999 Nucleolar ARF sequesters Mdm2 and activates p53. Nat Cell Biol 1: 20-26.

Wong TN, Ramsingh G, Young AL, Miller CA, Touma W, Welch IS, Lamprecht TL, Shen D, Hundal J, Fulton RS, et al. 2015. Role of TP53 mutations in the origin and evolution of therapy-related acute myeloid leukaemia. Nature 518: 552-555.

Xiong S, Pant V, Suh YA, Van Pelt CS, Wang Y, Valentin-Vega YA, Post SM, Lozano G. 2010. Spontaneous tumorigenesis in mice overexpressing the p53-negative regulator Mdm4. Cancer Res 70: 7148-7154.

Yang A, Walker N, Bronson R, Kaghad M, Oosterwegel M, Bonnin J, Vagner C, Bonnet H, Dikkes P, Sharpe A, et al.
2000. p73-deficient mice have neurological, pheromonal and inflammatory defects but lack spontaneous tumours. Nature 404: 99-103.

Yu J, Zhang L, Hwang PM, Kinzler KW, Vogelstein B. 2001. PUMA induces the rapid apoptosis of colorectal cancer cells. Mol Cell 7: 673-682.

Zhang Y, Xiong Y, Yarbrough WG. 1998. ARF promotes MDM2 degradation and stabilizes p53: ARF-INK4a locus deletion impairs both the $\mathrm{Rb}$ and $\mathrm{p} 53$ tumor suppression pathways. Cell 92: 725-734.

Zindy F, Eischen CM, Randle DH, Kamijo T, Cleveland JL, Sherr CJ, Roussel MF. 1998. Myc signaling via the ARF tumor suppressor regulates p53-dependent apoptosis and immortalization. Genes Dev 12: 2424-2433. 


\section{$\&_{\mathrm{CSH}}^{\infty} \&$ Cold Spring Harbor

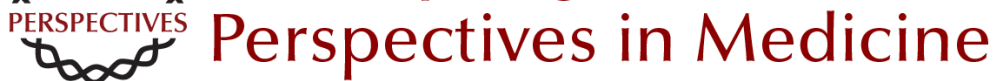

\section{Genome Stability Requires p53}

Christine M. Eischen

Cold Spring Harb Perspect Med 2016; doi: 10.1101/cshperspect.a026096

Subject Collection The p53 Protein

Targeting the MDM2-p53 Protein-Protein Interaction for New Cancer Therapy: Progress and Challenges

Shaomeng Wang, Yujun Zhao, Angelo Aguilar, et al.

Structural Evolution and Dynamics of the p53

Proteins

Giovanni Chillemi, Sebastian Kehrloesser,

Francesca Bernassola, et al.

Exploiting the p53 Pathway for Therapy Chit Fang Cheok and David Philip Lane

The Regulation of Cellular Functions by the p53

Protein: Cellular Senescence

Crystal A. Tonnessen-Murray, Guillermina Lozano and James G. Jackson

The Transactivation Domains of the p53 Protein Nitin Raj and Laura D. Attardi

The Evolution of the Ribosomal Protein-MDM2p53 Pathway

Chad Deisenroth, Derek A. Franklin and Yanping Zhang

Somatic TP53 Mutations in the Era of Genome

Sequencing

Pierre Hainaut and Gerd P. Pfeifer

The Paradox of p53: What, How, and Why?

Yael Aylon and Moshe Oren
Control of Cellular Aging, Tissue Function, and Cancer by p53 Downstream of Telomeres Caitlin M. Roake and Steven E. Artandi

Inherited TP53 Mutations and the $\mathbf{L i}-$ Fraumeni Syndrome

Tanya Guha and David Malkin

TP53 Mutations in Hypodiploid Acute Lymphoblastic Leukemia

Evan Q. Comeaux and Charles G. Mullighan

Transcriptional Regulation by Wild-Type and

Cancer-Related Mutant Forms of p53

Neil T. Pfister and Carol Prives

The Inherited p53 Mutation in the Brazilian

Population

Maria Isabel Achatz and Gerard P. Zambetti

TP53 Mutations in Breast and Ovarian Cancer Laxmi Silwal-Pandit, Anita Langerød and Anne-Lise Børresen-Dale

p53 and the Carcinogenicity of Chronic Inflammation

Andrei V. Gudkov and Elena A. Komarova

Oncogenic Mutant p53 Gain of Function

Nourishes the Vicious Cycle of Tumor

Development and Cancer Stem-Cell Formation

Yoav Shetzer, Alina Molchadsky and Varda Rotter

For additional articles in this collection, see http://perspectivesinmedicine.cshlp.org/cgi/collection/ 